$\begin{array}{rr}\text { FIT(1)PATOLOGI } & \text { Volume } 11, \text { Nomor 5, Oktober } 2015 \\ \text { I N D ON ES IA } & \text { Halaman } 175-178 \\ \text { ISSN: } 0215-7950 & \text { DOI: } 10.14692 / \text { jfi.11.5.175 }\end{array}$

TEMUAN PENYAKIT BARU

\title{
Laporan Pertama Infeksi Begomovirus pada Tanaman Mentimun di Bali
}

\section{First Report on Begomovirus Infection on Cucumber in Bali}

\author{
I Dewa Made Putra Wiratama ${ }^{1}$, Gusti Ngurah Alit Susanta Wirya ${ }^{1 *}$, \\ Ni Nengah Putri Adnyani ${ }^{1}$, I Dewa Nyoman Nyana ${ }^{1}$, Gede Suastika ${ }^{2}$ \\ ${ }^{1}$ Universitas Udayana, Denpasar 80225 \\ ${ }^{2}$ Institut Pertanian Bogor, Bogor 16680
}

\begin{abstract}
ABSTRAK
Tanaman mentimun dengan gejala daun menguning mulai banyak ditemukan pada sejumlah pertanaman mentimun di Desa Apuan dan Desa Bangli, Provinsi Bali. Penyakit ini diduga berasosiasi dengan Begomovirus karena gejalanya mirip dengan infeksi Begomovirus yang dilaporkan terjadi pada tanaman mentimun di Jawa. Selain itu, kutukebul (Bemisa tabaci) ditemukan di lapangan. Penelitian ini bertujuan mengidentifikasi penyebab penyakit daun kuning pada tanaman mentimun. Deteksi dan identifikasi virus dilakukan dengan teknik polymerase chain reaction menggunakan pasangan primer universal Begomovirus, SPG1/SPG2. Pita DNA berukuran 912 pb berhasil diamplifikasi dari sampel tanaman. Analisis hasil sikuensing nukleotida menunjukkan bahwa Begomovirus yang menginfeksi tanaman mentimun di Bali mempunyai nilai kemiripan tertinggi (91\%) dengan Squash leaf curl China virus (SLCCNV) isolat Malaysia. Penelitian ini merupakan laporan pertama infeksi SLCCNV di Bali.
\end{abstract}

Kata kunci: Bemisia tabaci, PCR, sikuensing, Squash leaf curl China virus

\begin{abstract}
Leaf yellowing symptoms was commonly found in cucumber plants in Bali provinces, i.e. in Apuan and Bangli villages recently. Begomovirus infection is suspected as the causal agent, due to similar symptoms previously reported from cucumber plants in Java. In addition, Bemisia tabaci was observed in the field. The objective of this research was to identify the causal agent of leaf yellowing disease of cucumber in Bali. Virus detection and identification was conducted by polymerase chain reaction method using universal primers for Begomovirus, i.e. SPG1/SPG2. DNA fragment of 912 bp in size was successfully amplified from leaf samples. Analysis of nucleotide sequencing indicated that Begomovirus infecting cucumber plants in Bali has the highest homology (91\%) with Squash leaf curl China virus (SLCCNV) isolate from Malaysia. This is the first report of SLCCNV infection in Bali.
\end{abstract}

Key words: Bemisia tabaci, PCR, sequencing, Squash leaf curl China virus

*Alamat penulis korespondensi: Program Studi Bioteknologi Pertanian, Program Pascasarjana, Universitas Udayana, Jalan PB. Sudirman, Denpasar, Bali 80225.

Tel: 0361-223797, Faks: 0361-247962; surel:alitsusanta@yahoo.com 
Gejala infeksi virus pada tanaman mentimun banyak ditemukan pada saat kegiatan survei di Desa Apuan dan Desa Bangli, Kecamatan Baturiti, Kabupaten Tabanan, Bali pada bulan September 2014. Gejala penyakit pada tanaman mentimun tersebut berupa daun menguning dengan tulang daun tetap hijau atau vein banding (Gambar 1). Insidensi penyakit mencapai 80\% dan pada saat pengamatan banyak ditemukan serangga kutukebul (Bemisia tabaci) di bagian bawah daun mentimun. Kutukebul diketahui merupakan serangga vektor virus, terutama dari kelompok Begomovirus (Brown et al. 2001; Jones 2003).

Mizutani et al. (2011) pertama kali melaporkan adanya infeksi Begomovirus pada tanaman mentimun dengan gejala daun keriting di Klaten, Jawa Tengah. Septariani et al. (2014) juga melaporkan tanaman mentimun bergejala kuning di Jawa Barat, Jawa Tengah dan Daerah Istimewa Yogyakarta dan mengidentifikasi penyebab penyakit tersebut ialah Tomato leaf curl New Delhi virus (TLCNDV), salah satu anggota Begomovirus. Begomovirus dilaporkan pertama kali menginfeksi tanaman labu (Cucurbit maxima) di California (US) pada tahun 1977. Virusnya dinamakan Squash leaf curl geminivirus (SLCV) yang menyebabkan daun keriting. Beberapa tahun kemudian, yaitu pada tahun 1981, infeksi SLCV juga dilaporkan di Meksiko (Flock dan Mayhew 1981). Gejala penyakit meliputi daun keriting, melepuh, menguning, mosaik, dan perubahan bentuk buah (Shtayeh et

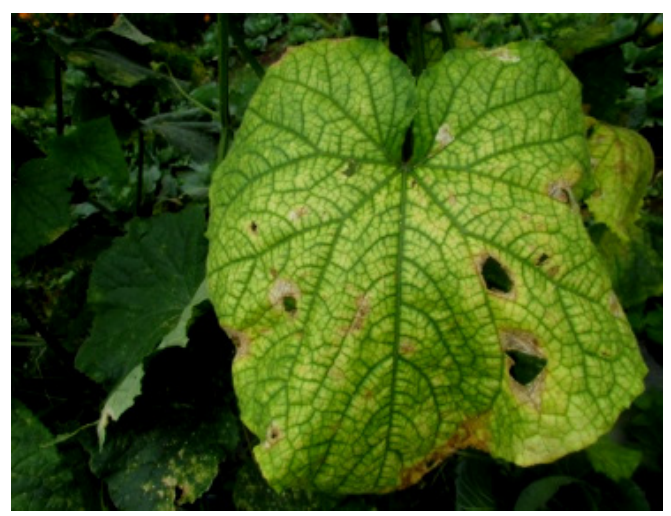

a al. 2010). Penyakit daun menguning dan kerdil pada melon yang disebabkan oleh Watermelon curly mottle virus dilaporkan di Arizona (US) (Brown dan Nelson 1989). Penyakit daun kuning yang disebabkan oleh Cucurbit leaf curl virus dilaporkan di Amerika Tengah, Meksiko, dan Amerika Serikat (Arizona, Texas dan California) (Brown et al. 2002). Infeksi SLCV juga dilaporkan telah menginfeksi tanaman Cucurbitaceae di Filipina (Kon et al. 2003) dan labu di Taiwan (Tsai et al. 2011). Begomovirus lain yang telah dilaporkan menginfeksi tanaman Cucurbitaceae ialah Tomato leaf curl virus yang menyebabkan daun kuning pada labu di Thailand (Samretwanich et al. 2000), Squash leaf curl virus-Vietnam dan Loofa yellow mosaic virus-Vietnam menginfeksi tanaman Cucurbitaceae di Vietnam (Revill et al. 2003).

Berdasarkan deskripsi gejala penyakit yang dikumpulkan, tanaman mentimun di Bali diduga diinfeksi Begomovirus. Oleh karena itu, dilakukan deteksi Begomovirus terhadap sampel tanaman mentimun yang dikumpulkan dari Desa Apuan dan Bangli.

Metode yang digunakan untuk mendeteksi Begomovirus ialah polymerase chain reaction dengan primer universal Begomovirus SPG1/SPG2. Primer universal Begomovirus tersebut akan mengamplifikasi bagian gen transcriptional activator protein (TrAp) dan replication-associated protein (Rep) dengan ukuran target $\pm 900 \mathrm{pb}$ (Li et al. 2004). Ekstraksi DNA total dari sampel daun mentimun menggunakan metode Doyle

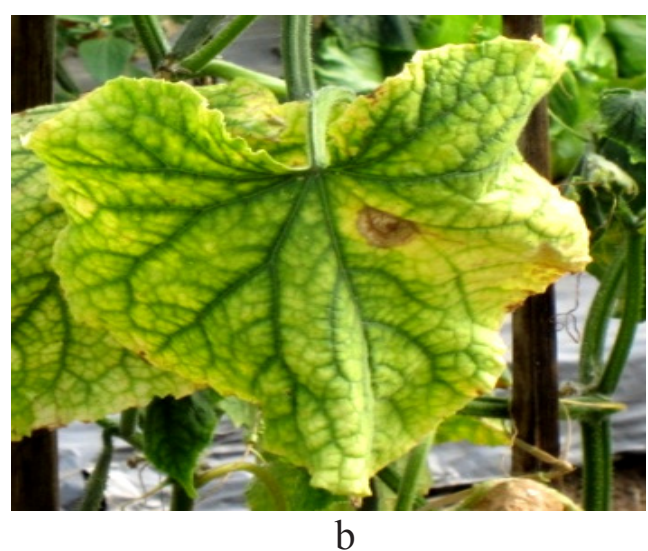

Gambar 1 Variasi gejala Begomovirus pada tanaman mentimun di Bali. a, gejala menguning dan menggulung; $b$, gejala menguning dan tulang daun menjari. 
dan Doyle (1987). Reaksi amplifikasi DNA didahului dengan 1 siklus pradenaturasi pada $94{ }^{\circ} \mathrm{C}$ selama 5 menit, dilanjutkan 35 siklus dengan tahapan denaturasi pada $94^{\circ} \mathrm{C}$ selama 1 menit, aneling pada $50^{\circ} \mathrm{C}$ selama 1 menit, dan sintesis DNA pada $72^{\circ} \mathrm{C}$ selama 10 menit. Hasil amplifikasi DNA dianalisis dengan elektroforesis pada gel agarosa 1\%. DNA hasil amplifikasi selanjutnya digunakan untuk sikuensing nukleotida. Data hasil sikuensing digunakan untuk menganalisis homologi dan membandingkan tingkat kesamaannya dengan data yang ada di GenBank menggunakan perangkat lunak Bioedit versi 7.0.5

Pita DNA berukuran 912 pb berhasil diamplifikasi dari sampel asal Desa Apuan dan Desa Bangli (Gambar 2). Hasil amplifikasi

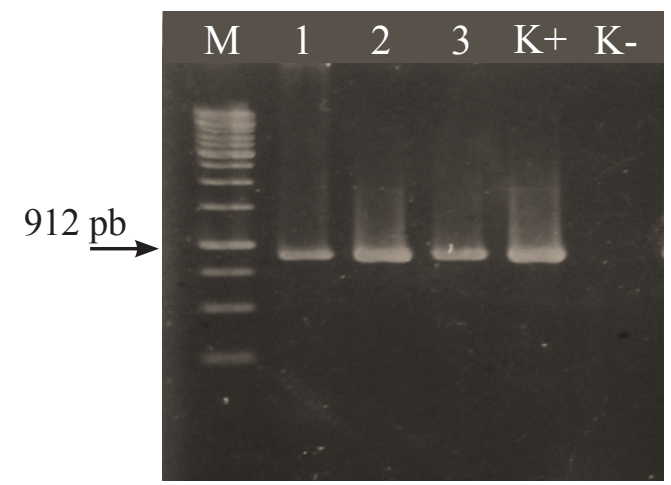

Gambar 2 Hasil amplifikasi Begomovirus penyebab penyakit kuning pada tanaman mentimun menggunakan pasangan primer SPG1/SPG2 yang divisualisasikan pada gel agarosa 1\%. M, penanda DNA $1 \mathrm{~kb}$ (Thermo Scientific, US); 1, sampel dari Desa Apuan; 2, sampel dari Desa Bangli 1; 3, sampel dari Desa Bangli 2; K+, kontrol positif; K-, kontrol negatif. tersebut membuktikan adanya infeksi Begomovirus pada tanaman sampel. Lebih lanjut, hasil analisis sikuensing nukleotida menunjukkan bahwa 3 isolat Begomovirus asal mentimun tersebut memiliki homologi $\geq 89 \%$ dengan Squash leaf curl China virus (SLCCNV) dan 82\% dengan Tomato leaf curl New Delhi virus (ToLCNDV) (Tabel 1). Sesuai dengan pernyataan Fauquet dan Stanley (2005) bahwa semua isolat Begomovirus dapat dikategorikan ke dalam satu spesies virus yang sama apabila mempunyai kemiripan basa lebih dari $89 \%$ maka isolat SLCCNV asal Bali yang menginfeksi pertanaman mentimun adalah spesies yang sama dengan SLCCNV dari Malaysia, Vietnam, India, Cina, dan Thailand. Ketiga isolat tersebut selanjutnya disebut isolat SLCCNV Apuan, isolat SLCCNV Bangli 1, dan isolat SLCCNV Bangli 2.

Berdasarkan hasil identifikasi di atas dapat disimpulkan bahwa tanaman mentimun yang memperlihatkan gejala menguning dengan tulang daun tetap hijau yang banyak ditemukan di Desa Apuan dan Desa Bangli, Kecamatan Baturiti, Kabupaten Tabanan, Bali berasosiasi dengan infeksi SLCCNV. Infeksi SLCCNV tersebut belum pernah dilaporkan di Indonesia. Penelitian dasar untuk mengetahui karakter molekuler dan biologi SLCCNV perlu dilakukan sebagai landasan menyusun strategi pengendalian penyakit.

\section{DAFTAR PUSTAKA}

Brown JK, Nelson MR. 1989. Characterisation of Watermelon curly mottle virus, a Geminivirus distinct from Squash

Tabel 1 Tingkat homologi (\%) sikuen nukleotida antara Begomovirus asal tanaman mentimun Bali dengan beberapa isolat Begomovirus yang dilaporkan di GenBank

\begin{tabular}{llccc}
\hline Isolat Begomovirus & No Aksesi & \multicolumn{3}{c}{ Tingkat Homologi Isolat Begomovirus di Bali (\%) } \\
\cline { 3 - 5 } di GenBank & & Apuan & Bangli 1 & Bangli 2 \\
\hline SLCCNV Malaysia & EF197940 & 91 & 91 & 91 \\
SLCCNV Vietnam & AF509743 & 90 & 90 & 90 \\
SLCCNV India & AY184487 & 90 & 90 & 90 \\
SLCCNV Cina & AM260206 & 90 & 90 & 89 \\
SLCCNV Thailand & AB330078 & 89 & 90 & 89 \\
ToLCNDV Spanyol & KF749225 & 82 & 82 & 82 \\
\hline
\end{tabular}

SLCCNV, Squash leaf curl China virus; ToLCNDV, Tomato leaf curl New Delhi virus 
leaf curl virus. Ann Apl Biol. 115(2):243-252. DOI: http://dx.doi. org/10.1111/j.1744-7348.1989.tb03383.x.

Brown JK, Idris, AM, Rogan D, Hussein MH, Palmieri M. 2001. Melon chlorotic leaf curl virus, a new Begomovirus associated with Bemisia tabaci infestations in Guatemala. Plant Dis. 85(9):1027. DOI: http://dx.doi. org/10.1094/PDIS.2001.85.9.1027C.

Brown J K, Idris AM, Alteri C, Stenger DC. 2002. Emergence of a new cucurbitinfecting Begomovirus species capable of forming viable reassortants with related viruses in the Squash leaf curl virus cluster. Phytopathology. 92(7):734742. DOI: http://dx.doi.org/10.1094/ PHYTO.2002.92.7.734.

Doyle JJ, Doyle JL. 1987. A rapid DNA isolation procedure for small quantities of fresh leaf tissues. Phytochem Bull. 19:11-15.

Fauquet CM, Stanley J. 2005. Revising the way we conceive and name viruses below the species level: A review of Geminivirus taxonomy calls for new standardized isolate descriptors. Arch Virol. 150(10):21512179. DOI: http://dx.doi.org/10.1007/ s00705-005-0583-0.

Flock RA, Mayhew DE. 1981. Squash leaf curl, a new disease of cucurbits in California. Plant Dis. 65:75-76. DOI: http://dx.doi.org/10.1094/PD-65-75.

Jones DR. 2003. Plant viruses transmitted by whiteflies. Eur J Plant Pathol. 109(3):195-219. DOI: http://dx.doi. org/10.1023/A:1022846630513.

Kon T, Dolores LM, Bajet NB, Hase S, Takahashi H, Ikegami M. 2003. Molecular characterization of a strain of Squash leaf curl China virus from the Philippines. J Phytopathol. 151(10):535-539. DOI: http://dx.doi.org/10.1046/j.14390434.2003.00764.x.
Li R, Salih S, Hurtt S. 2004. Detection of geminiviruses in sweetpotato by polymerase chain reaction. Plant Dis. 88(12):1347-1351. DOI: http://dx.doi. org/10.1094/PDIS.2004.88.12.1347.

Mizutani T, Daryono BS, Ikegami M, Natsuaki KT. 2011. First report of Tomato leaf curl New Delhi virus infecting cucumber in Central Java, Indonesia. Plant Dis. 95(11):1485. DOI: http://dx.doi. org/10.1094/PDIS-03-11-0196.

Revill PA, Ha CV, Porchun SC, Vu MT, Dale JL. 2003. The complete nucleotide sequence of two distinct Geminiviruses infecting cucurbits in Vietnam. Arch Virol. 148: 1523-1541. DOI: http://dx.doi. org/10.1007/s00705-003-0109-6.

Samretwanich K, Chiemsombat P, Kittipakorn K, Ikegami M. 2000. Yellow leaf disease of cantaloupe and wax gourd from Thailand caused by Tomato leaf curl virus. Plant Dis. 84(2):200. DOI: http://dx.doi.org/10.1094/ PDIS.2000.84.2.200C.

Septariani DN, Hidayat SH, Nurhayati E. 2014. Identifikasi penyebab penyakit daun keriting kuning pada tanaman mentimun. J HPT Tropika. 14(1):80-86.

Shtayeh MSA, Jamous RM, Husein EY, Alkhader MY. 2010. First report of squash leaf curl in squash (Cucurbita pepo), melon (Cucumis melo), and cucumber (Cucumber sativus) in the Northern West Bank of the Palestinan Authority. Plant Dis. 94(5):640. DOI: http://dx.doi.org/10.1094/PDIS-945-0640B.

Tsai WS, Hu CJ, Shung DP, Lee LM, Wang JT, Kenyon L. 2011. First report of Squash leaf curl Philippines virus Infecting Chayote (Sechium edule) in Taiwan. Plant Dis. 95(9):1197. DOI: http://dx.doi. org/10.1094/PDIS-04-11-0282. 